\title{
Steroidogenesis during postnatal testicular development of Galea spixii
}

\author{
P R S Santos ${ }^{1}$, F D Oliveira ${ }^{1}$, M A M Arroyo ${ }^{1}$, M F Oliveira ${ }^{2}$, P Castelucci ${ }^{3}$, A J Conley ${ }^{4}$ and \\ A C Assis Neto ${ }^{1}$ \\ ${ }^{1}$ Department of Surgery, Faculty of Veterinary Medicine and Animal Science, São Paulo University, São Paulo, Brazil, \\ ${ }^{2}$ Department of Animal Science, Federal Rural University of the Semi-arid Northeastern Region (UFERSA), Mossoró, \\ Brazil, ${ }^{3}$ Department of Anatomy, Institute of Biomedical Sciences, University of São Paulo, São Paulo, Brazil and \\ ${ }^{4}$ Population Health \& Reproduction, School of Veterinary Medicine, University of California, Davis, California, USA
}

Correspondence should be addressed to A C Assis Neto; Email: antonioassis@usp.br

\begin{abstract}
The androgen/estrogen balance is essential for normal sexual development and reproduction in mammals. Studies performed herein investigated the potential for estrogen synthesis in cells of the testes of a hystricomorph rodent, Galea spixii. The study characterized the expression of the key enzymes responsible for estrogen and androgen synthesis, cytochromes P450 aromatase (P450arom), $17 \alpha$-hydroxylase/17,20-lyase (P450c17) respectively, as well as the redox partner NADPH cytochrome P450 oxido-reductase (CPR) required to support electron transfer and catalysis of these $\mathrm{P450s}$, by immunohistochemistry (IHC) and quantitative polymerase chain reaction (qPCR) analysis, throughout postnatal sexual development. Testes (immature, pre-pubertal, pubertal and post-pubertal) were collected, fixed for IHC (CYP19, CYP17 and CPR) and stored frozen for qPCR for the relevant gene transcripts (Cyp19a1 and Cyp17a1). Expression of P450c17 was significantly elevated at the pre-pubertal and pubertal stages. Based on IHC, P450c17 was expressed only in Leydig cell clusters. The expression of P450arom was detectable at all stages of sexual development of Galea spixii. IHC data suggest that estrogen synthesis was not restricted to somatic cells (Leydig cells/Sertoli cells), but that germ cells may also be capable of converting androgens into estrogens, important for testicular function and spermatogenesis.

Reproduction (2017) 154 645-652
\end{abstract}

\section{Introduction}

Androgens and estrogens are essential for sexual differentiation and ultimately for fertility, helping to shape secondary sexual characteristics and regulate reproductive function. The importance of both androgens and estrogens is as true with respect to male development and successful gametogenesis (Rommerts 1988, Carreau et al. 2004) as it is for females. Cholesterol is the precursor of all steroids. It is transported across the membrane of mitochondria to the inner mitochondrial membrane, the site of expression of side chain cleavage cytochrome P450 (P450scc), the enzyme that utilizes cholesterol for the synthesis of pregnenolone in steroidogenic tissues. Pregnenolone is the universal substrate for synthesis of all other steroids including progesterone, which is catalyzed by the enzyme $3 \beta$-hydroxysteroid dehydrogenase/ $\Delta 5-\Delta 4$ isomerase $(3 \beta-H S D)$ that resides in both smooth endoplasmic reticulum (microsomal compartment) and mitochondria. The first committed step in the synthesis of androgens is catalyzed by $17 \alpha$-hydroxylase/17,20lyase cytochrome P450 (P450c17) that resides exclusively in the microsomal compartment. This enzyme can utilize either pregnenolone or progesterone as a substrate, depending on species (Conley \& Bird 1997), synthesizing dehydroepiandrosterone or androstenedione respectively. Androstenedione can be reduced subsequently to testosterone by $17 \beta-\mathrm{HSD}$ (17 $\beta$-hydroxysteroid dehydrogenase). Androstenedione and testosterone are substrates for aromatase cytochrome P450 (P450arom), also in the microsomal compartment, for synthesis of estrone and estradiol. Hence, androgen and estrogen synthesis are critically dependent on microsomal P450c17 and P450arom expression, as well as $3 \beta-H S D$. Like all microsomal P450 enzymes, both P450c17 and P450arom require the redox binding protein, NADPH cytochrome P450 oxido-reducatse (CPR) as the sole source of reducing equivalents necessary to fuel androgen and estrogen synthesis. The enzymes required for androgen and estrogen synthesis are not always expressed in the same cells, and compartmentalization is both tissue and species dependent (Tsai-Morris et al. 1985). Localization of the enzymes in tissues cannot be assumed and therefore requires investigation in all species. 
It has long been known that normal testis development and spermatogenesis are controlled by gonadotropins and testosterone. More recently, it has become obvious that estrogens play an equally important role in the maintenance of sperm production in men, mice and other species (Carreau et al. 1999). For instance, the balance of androgen and estrogen is known to influence Sertoli cell proliferation in pigs (Berger et al. 2013). Inhibition of estrogen synthesis in the neonatal period increases Sertoli cell numbers in the porcine testis and thereby increases sperm production capacity (Berger et al. 2013). The opposite appears true of some other species. For instance, the lack of P450arom expression leads to testicular degeneration and loss of fertility in mice after a year of age (Robertson et al. 1999). Clearly, testicular estrogen synthesis is important in the maintenance of spermatogenesis and fertility in a variety of species (Carreau et al. 2007).

Numerous studies have been conducted to identify the cells within the testis that are responsible for estrogen synthesis. Rat Sertoli cells are a major source of estrogens in immature animals, although the Leydig cells synthesize estrogen in adult rats (Tsai-Morris et al. 1985). Leydig cells are likely the major cellular site of synthesis of estrogen outside the brain in male mammals (Conley \& Hinshelwood 2001). Aromatase immunoreactivity has been observed by immunohistochemistry in the testis of various species; pig (Conley 1996), the white rat (Bilinska et al. 2001, Kotula-Balak et al. 2003), black bear (Tsubota et al. 1997), the bison (Kopera et al. 2010) and deer (Schon \& Blottner 2008), and expression has been described in somatic and germ cells. However, it has been suggested that in boars, the Leydig cells are the only source of estrogen (Mutembei et al. 2005). Similarly for the stallion, aromatase expression appeared dominant in Leydig cells (Eisenhauer et al. 1994), although data suggest there may be an additional source of estrogens in germ cells (Sipahutar et al. 2003). The authors are unaware of any studies that have been conducted to determine the partitioning of androgen or estrogen synthesis in the testes of a hystricomorph rodent.

Galea spixii (Spix cavy) is an important hystricomorph rodent used for commercial production in parts of Brazil (Santos et al. 2012, 2014). To better understand testicular androgen and estrogen production, this study was conducted to examine the expression of steroidogenic enzymes, P450arom, P450c17 and the essential redox partner protein CPR by qPCR and immunohistochemistry, throughout pre- and post-natal sexual development.

\section{Materials and methods}

Testes from immature (1-15 days of age, $n=3$ ), pre-pubertal (30 days, $n=3$ ), pubertal (45-90 days, $n=3$ ) and post-pubertal (120 days, $n=3$ ) Galea spixii were studied. The animals were collected in Northeastern Brazil (3782003900W,
681204300S), in Mossoró City, Rio Grande do Norte. The Ethics Committee for the Use of Animals at the University of São Paulo (FMVZ/USP) authorized all experimental procedures (protocol: 2729/2012), and the capture and captivity of the cavies were authorized by the Brazilian Institution responsible for wild animal care (Instituto Brasileiro do Meio Ambiente, IBAMA, protocol: 2028236/2008). The testes of animals were collected by orchiectomy. During the procedure, the older animals were anesthetized with $0.025 \mathrm{mg} / \mathrm{mL}$ atropine sulfate (s.c.) and $0.2 \mathrm{~mL} / \mathrm{kg}$ Zoletil (i.m.). Subsequently, the testes of each animal were fixed by immersion in buffered neutral formalin, embedded in paraffin and sectioned at $5 \mu \mathrm{m}$ for IHC. All histological and IHC analysis was conducted at the University of Sao Paulo (FMVZ/USP)

\section{Immunohistochemistry}

Fixed tissues were deparaffinized and antigen retrieval was performed using a citrate-based buffer $(\mathrm{pH} 6.0$ with detergent, Antigen Retrieval Buffer, PMB1-125, SpringBio), and endogenous peroxidases were quenched with $0.3 \% \mathrm{H}_{2} \mathrm{O}_{2}$ in methanol for $15 \mathrm{~min}$. After rinsing in phosphate buffered saline (PBS), slides were blocked with ProteinBLock (DPB-125, SpringBio) for $20 \mathrm{~min}$ at room temperature. The sections were then incubated in humidified chambers overnight at $4-8^{\circ} \mathrm{C}$ with the following primary antisera: anti-P450arom (1:50, rabbit polyclonal, ab18995, Abcam), anti-P450c17 (1:600, goat polyclonal, ab48019, Abcam), anti-CPR (1:500, rabbit polyclonal, ab13513, Abcam). Antisera were diluted in PBS prior to immunolabeling. After incubation with the primary antisera, slides were rinsed for $5 \mathrm{~min}$ in PBS and incubated with N-Histofine Simple Stain Mouse MAX PO (Nichirei Biosciences) for $30 \mathrm{~min}$ prior to detection using the DAB kit (DAB-125, SpringBio). Slides were then counterstained with hematoxylin and mounted in permount (FISH-SP15-500, Thermo Fisher Scientific).

\section{IHC fluorescence method}

For aromatase IHC fluorescence, fixed tissues were deparaffinized and antigen retrieval was performed using a citrate-based buffer ( $\mathrm{pH} 6.0$ with detergent, Antigen Retrieval Buffer, PMB1-125, SpringBio), and endogenous peroxidases were quenched with $0.3 \% \mathrm{H}_{2} \mathrm{O}_{2}$ in methanol for $15 \mathrm{~min}$. Then, the sections were immersed in 10\% normal horse serum solution (NHS) and 1.5\% Triton (Sigma) in PBS for $45 \mathrm{~min}$ at room temperature. Then, the samples were incubated with primary antibody (anti-P450arom, 1:200, rabbit polyclonal, ab18995, Abcam) for $24 \mathrm{~h}$. After 24h, the samples were again subjected to washes with PBS (three times for $10 \mathrm{~min}$ each) and were further incubated with a secondary antibody (Donkey anti-rabbit IgG 488, 1:500, Molecular Probe). The tissues were immersed in 2.6-diamino-2-phenylindole dihydrochloride (DAPI) for three minutes to stain the nuclei of all the cells. Subsequently, the tissues were washed in PBS ( 3 times for $5 \mathrm{~min}$ each). Then, the slides were covered with a glycerol coverslip buffered in $0.5 \mathrm{~mol} / \mathrm{L}$ calcium carbonate buffer ( $\mathrm{pH}$ 8.6). Observations were performed with a Nikon 80i fluorescence microscope using the Nis Elements program. 


\section{Real-time PCR}

Tissue samples of testes removed at surgery were immersed in RNAlater Stabilization Solution (Ambion), transported to the laboratory and then stored at $-80^{\circ} \mathrm{C}$ until processing for realtime quantitative polymerase chain reaction ( $q P C R$ ).

Samples (50-100 mg) were homogenized on ice in TRIzol Reagent (Ambion) and total RNA from all testes was extracted according to the manufacturer's instructions. Total RNA was quantified in all samples using a NanoDrop 2000c Spectrophotometer (Thermo Scientific). All preparations had RNA concentrations $>300 \mathrm{ng} / \mu \mathrm{L}$. RNA was stored at $-80^{\circ} \mathrm{C}$ and used for real-time qPCR.

For real-time qPCR, amplification was performed using a High-Capacity cDNA Reverse Transcription Kit (Applied Biosystems). Based on information of mouse and guinea pig in NCBI GenBank, G. spixii primers and probes were designed using Primer Express, ver. 1.5 (Applied Biosystems). All primers and probes were synthesized by Sigma-Aldrich and were used at a concentration of $10 \mathrm{mM}$. Primer sequences and corresponding base sites are listed in Table 1. For aromatase (Cyp19a1): >gi|156139071|ref|NM_007810.3| Mus musculus cytochrome P450, family 19, subfamily a, polypeptide 1 (Cyp19a1), mRNA; >gi|1039792035|ref|XM_006510805.3| PREDICTED: Mus musculus cytochrome P450, family 19, subfamily a, polypeptide 1 (Cyp19a1), transcript variant X1, mRNA; >gi|1039792036|ref|XM_006510806.3| PREDICTED: Mus musculus cytochrome P450, family 19, subfamily a, polypeptide 1 (Cyp19a1), transcript variant X2, mRNA; >gi|1039792037|ref|XM_017313123.1| PREDICTED: Mus musculus cytochrome P450, family 19, subfamily a, polypeptide 1 (Cyp19a1), transcript variant X3, mRNA; >gi|1039792039|ref|XM_006510809.3| PREDICTED: Mus musculus cytochrome P450, family 19, subfamily a, polypeptide 1 (Cyp 19a 1), transcript variant X4, mRNA; >gi|10 39792040|ref|XM_006510808.3| PREDICTED: Mus musculus cytochrome P450, family 19, subfamily a, polypeptide 1 (Cyp19a1), transcript variant X5, mRNA; >gi|1039792041|re f|XM_011242661.2| PREDICTED: Mus musculus cytochrome P450, family 19, subfamily a, polypeptide 1 (Cyp19a1), transcript variant X6, mRNA; and for Cyp17 (Cyp17a1): >gi|160948600|ref|NM_007809.3| Mus musculus cytochrome P450, family 17, subfamily a, polypeptide 1 (Cyp17a1), mRNA. Thermal cycling conditions were as follows: holding stage at $95^{\circ} \mathrm{C}$ for $15 \mathrm{~min}$, followed by cycling stage, 40 cycles of $10 \mathrm{~s}$ at $95^{\circ} \mathrm{C}$ and $30 \mathrm{~s}$ at $63^{\circ} \mathrm{C}$, and finally, melting curve stage, $10 \mathrm{~s}$ at $95^{\circ} \mathrm{C}, 30 \mathrm{~s}$ at $63^{\circ} \mathrm{C}$ and $10 \mathrm{~s}$ at $95^{\circ} \mathrm{C}$, were performed in SetpOnePlus Real-Time Systems (Applied Biosystems) using a 96-well optical reaction plate. Each sample was run in triplicate. Gene expression levels were recorded as quantification cycle values and then analyzed using the $\Delta \Delta$ Ct method. Real-time gPCR data for genes of interest in testicular tissue of G. spixii were normalized with glyceraldehyde-3-phosphate dehydrogenase $(G A P D H)$ and ACTB ( $\beta$-actin).

\section{Results}

The expression of P450c17, P450arom and CPR in testicular parenchyma varied during the sexual development of Galea spixii (Table 2) based on immunoreactive intensity. Cytochrome P450c17 expression in testicular parenchyma showed a positive reaction only in Leydig cell clusters located in the interstitial space at all stages of sexual development (Fig. 1). Expression of the Cyp17 gene was dynamic during sexual development. The immature phase exhibited a higher level of Cyp17 expression, expression decreased during pre-pubertal stage and increased again in the pubertal phase (Fig. 2).

For the P450arom immunoreactivity, expression was also stronger in Leydig than other cells and appeared to change with the stage of sexual development. In immature sexual phase, the expression was positive in the Leydig cells, as well in support cells (Sertoli cell). Immunoreactivity for P450arom was low in gonocytes in the seminiferous cords by comparison (Figs. 3A and 4A). In pre-pubertal males, Leydig cells were again immunopositive (Figs. 3B, 4B and 5A-C), as were Sertoli cells and some germ cells (spermatogonia). The P450arom immunoreactivity in the pubertal stage was positive in the Leydig cells, Sertoli cells and germ cells (spermatogonia, spermatocytes and round/elongated spermatids) (Figs. 3C, 4C and D). In post-pubertal animals, P450arom immunoreactivity was also strong in Leydig cell clusters, and less so in Sertoli cells and germ cells (spermatogonia, spermatocytes and round/ elongated spermatids) (Figs. 3D, 4E-F and 5D-F). The expression of the (Cyp19a1) gene increased during sexual development, increasing markedly in the post-pubertal phase (Fig. 6). The co-enzyme CPR, an enzyme that forms a complex with the enzymes P450c17 and P450arom was expressed in different cell types throughout the sexual development of Galea spixii. In immature and pre-pubertal animals, the expression for CPR appeared to be positive only in Leydig cells (Fig. 7A and B), but at puberty, was present in both Leydig cells as well in

Table 1 Primer sequences and probes used for real-time quantitative polymerase chain reaction, along with efficiency and correlation coefficient $\left(R^{2}\right)$ of the standard curve.

\begin{tabular}{lllll}
\hline & Accession no. & Foivard primer $\left(5^{\prime}-3^{\prime}\right)$ & Reverse primer $\left(5^{\prime}-3^{\prime}\right)$ & \multicolumn{1}{c}{$\boldsymbol{R}^{\mathbf{2}}$} \\
\hline CYP17al & KM_007809.3 & GCAGAGGTTTGACTTTGATGTG & TAAGATTGGGC TGTGGGTGT \\
CYP19al & NM_007810.3 & TGGTGGAAGTTTGTGTGGAG & GATGTTTGGTTTGATGAGGAGA \\
GAPDH & KM_008084 & CCAGAACATCATCCCTGCAT & GTTCAGCTCTGGGATGACCTT & 1.00 \\
ACTB & AF_508792.1 & GCAGATGTGGATCAGCAAG & AGGGTGTAACGCAGCAAAG & 1.00 \\
\hline
\end{tabular}

CYP19A1 (P450arom); CYP17a1 (P450c17); GAPDH (glyceraldehyde-3-phosphate dehydrogenase); ACTB ( $\beta$-actin). 
Table 2 Expression of steroidogenic enzymes in different cell types of testicular parenchyma during the postnatal sexual development in Galea spixii.

\begin{tabular}{|c|c|c|c|c|}
\hline & Immature & Prep Liberia I & Pubertal & Post-pubertal \\
\hline \multicolumn{5}{|l|}{ Cytochrome P450d7 } \\
\hline Leydig cells & +++ & +++ & +++ & +++ \\
\hline Myotd cells & --- & --- & --- & --- \\
\hline Sertoli cells & --- & --- & --- & --- \\
\hline Gonocytes/spermatogonia & --- & --- & --- & --- \\
\hline Sperm atocytes & --- & --- & --- & --- \\
\hline \multicolumn{5}{|l|}{ Spermatids } \\
\hline Round & --- & --- & --- & --- \\
\hline Elongated & --- & --- & --- & --- \\
\hline \multicolumn{5}{|l|}{ Cytocrirome $\mathrm{P} 450$ aromatase } \\
\hline Leydig cells & +++ & +++ & +++ & +++ \\
\hline Myoid cells & --- & --- & --- & --- \\
\hline Sertoli cells & +++ & + & + & + \\
\hline Gonocytes/spenmatogoma & + & + & ++ & ++ \\
\hline Spermatocytes & --- & --- & +++ & +++ \\
\hline \multicolumn{5}{|l|}{ Spermatids } \\
\hline Round & --- & --- & +++ & +++ \\
\hline Elongated & --- & --- & +++ & +++ \\
\hline \multicolumn{5}{|l|}{ Cytochrome NADPH reductase } \\
\hline Leydig cells & +++ & +++ & +++ & +++ \\
\hline Myojd cells & --- & --- & --- & --- \\
\hline Sertoli cells & --- & --- & --- & --- \\
\hline Gonocytes/spemiatogonia & --- & --- & --- & --- \\
\hline Sperm atocytes & --- & --- & --- & --- \\
\hline \multicolumn{5}{|l|}{ Spermatids } \\
\hline Round & --- & --- & +++ & +++ \\
\hline Elongated & --- & --- & +++ & +++ \\
\hline
\end{tabular}

the germ cells (round and elongated spermatids) (Fig. 7C and D). There was no evidence of expression in Sertoli cells or myoid cells.

\section{Discussion}

To the best of the author's knowledge, this is the first examination of steroidogenic enzyme expression in the testes of a hystricomorph rodent, Galea spixii. The key enzymes involved in androgen and estrogen synthesis were localized predominantly in Leydig cells through sexual maturation. However, secondary sites of expression included faint immunereactivity in Sertoli cells and germ cells in post-pubertal testes (Fig. 5). Localization in Leydig cells is consistent with observations in most other species studied and suggests that the interstitium is the major site of androgen and estrogen synthesis in the testis. Expression was relatively low in Sertoli cells but more convincing in germ cells of post-pubertal testis. Similar observations have been made in several other species including wild squirrel and wild raccoon dog (Qiang et al. 2003, Zhang et al. 2010). While previous studies have provided evidence of testicular P450 expression, ours is the first to examine quantitative CPR expression in testicular tissue during sexual development. Co-localization of P450c17 and P450arom supports the notion that androgen and estrogen synthesis is originating mainly in Leydig cells.
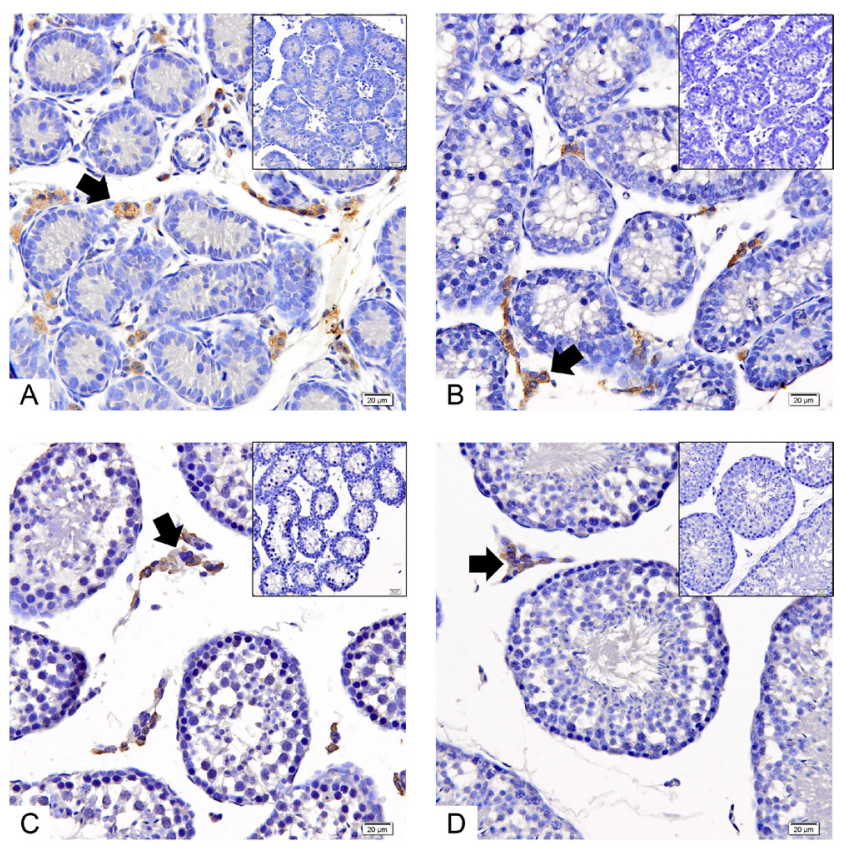

Figure 1 Immunohistochemical expression of cytochrome P450c17 expression in testicular parenchyma during development of Galea spixii. Note the positive staining in the Leydig cells (arrow), in the interstitial space. Inserts in micrographs represent negative controls. (A) Immature; (B) pre-pubertal; (C) pubertal; (D) post-pubertal. Photomicrography, IHC method, bar $=20 \mu \mathrm{m}$. 


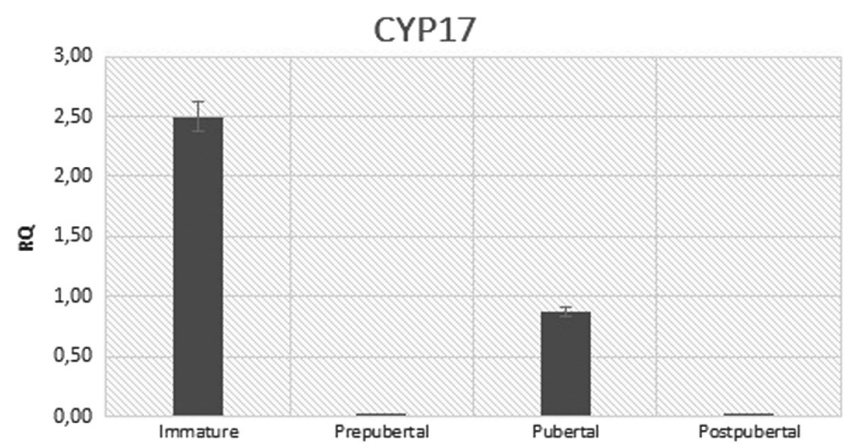

Figure 2 Relative gene expression normalized with GAPDH and $A C T B$ as reference genes of P450c17 (CYP17) in testis collected from immature, pre-pubertal, pubertal and post-pubertal G. spixii. Data are the means \pm S.E.M.

The P450arom enzyme is present in the membrane of the endoplasmic reticulum of the gonad, brain, placenta and adipose tissue in various rodents and other species, such as mouse, rat, bank vole, pig, horse and goat. In testes of these species, there is a difference in sites of expression, ranging from Leydig cells, Sertoli cells and germ cells. For example, only in Leydig cells in pigs,

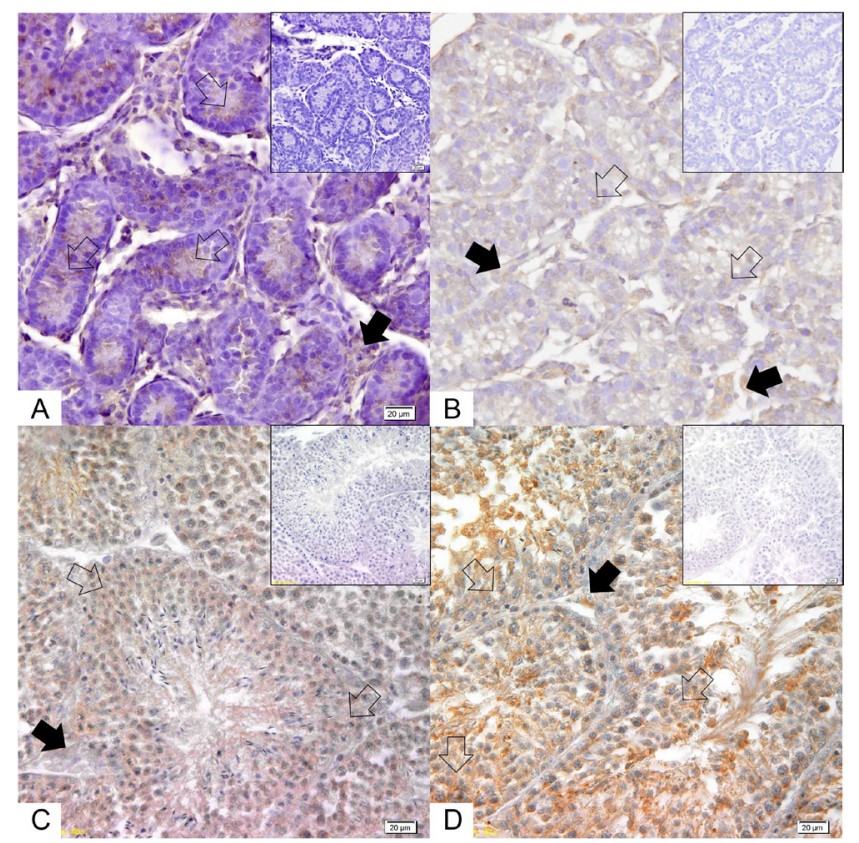

Figure 3 Immunohistochemical expression of cytochrome P450 aromatase expression in testicular parenchyma during development of Galea spixii. (A) Testes from immature males showing positive staining in undifferentiated support cells (seminiferous cords - empty arrow) and Leydig cells (bold arrow). (B) Testes from pre-pubertal males showing positive staining in Leydig cell clusters (bold arrow), with little expression in the seminiferous cords. (C) Testes from pubertal males and (D) post-pubertal males showed immunopositive reactions suggestive of expression in germ cells (spermatogonia, spermatocytes, round and elongated spermatids - empty arrow) and Leydig cells (bold arrow). Inserts represent negative controls. Bar $=20 \mu \mathrm{m}$.

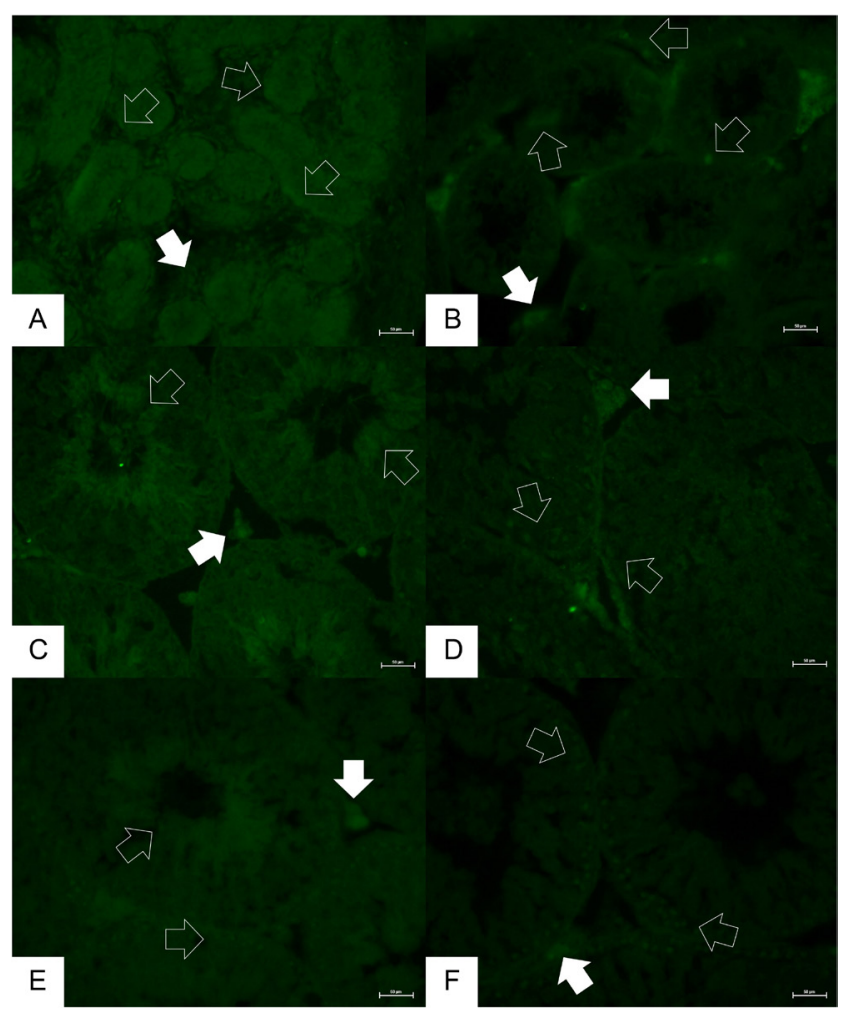

Figure 4 Aromatase IHC fluorescence in testicular parenchyma during development of Galea spixii. (A) Testes from immature males showing positive staining in undifferentiated support cells (seminiferous cords - empty arrow) and Leydig cells (bold arrow). (B) Testes from pre-pubertal males showing positive staining in Leydig cell clusters (bold arrow), with little expression in the seminiferous cords. (C and D) testes from pubertal males; and (D, E and F) post-pubertal males showed immunopositive reactions suggestive of expression in germ cells (spermatogonia, spermatocytes, round and elongated spermatids - empty arrow), and Leydig cells (bold arrow). The fluorescence of aromatase in pubertal and post-pubertal animals changes according to the stage of the cycle of the seminiferous epithelium. Bar $=50 \mu \mathrm{m}$.

in Leydig and germ cells in stallions and in Sertoli and germ cells in bank voles (Raeside \& Renaud 1983, Kurosumi et al. 1985, Nitta et al. 1993, Almadhidi et al. 1995, Conley et al. 1996, Bilinska et al. 1997, SchmalzFraczek et al. 1999, Conley \& Hinshelwood 2001).

In the present study, Galea spixii also had a change in expression of P450arom in testicular parenchyma. In immature and pre-pubertal animals, P450arom expression was restricted to Leydig cells. However, in addition, P450arom also appeared to be expressed in undifferentiated support cells in seminiferous cords, similar to the site of expression reported in immature rats (Tsai-Morris et al. 1985). Estradiol produced in the testis promotes gonocytes proliferation, in association with cell differentiation (Li et al. 1997). During puberty, expression of P450arom was mainly in Leydig cells, and also apparently in round and elongated spermatids. The same patterns of expression were reported in mice 


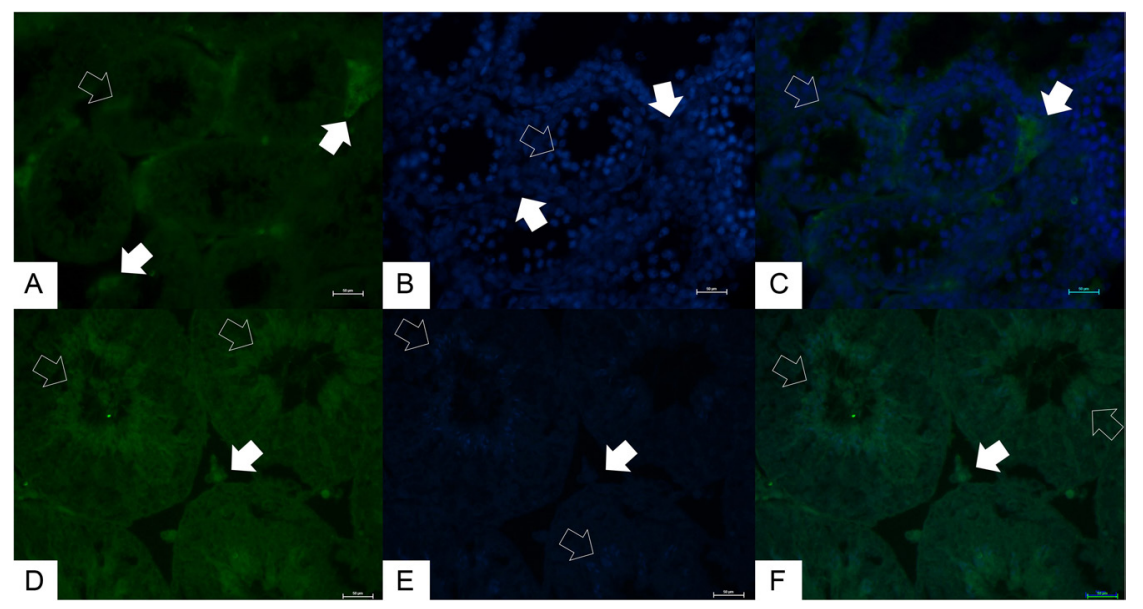

Figure 5 Aromatase IHC fluorescence. Aromatase staining in immunoreactive cells (A and D), DAPI staining in the nuclei of immunoreactive cells (B and $\mathrm{E}$ ) and the co-localization of aromatase and DAPI ( $\mathrm{C}$ and $\mathrm{F}$ ). The bold arrows indicate immunoreactive Leydig cells stained for aromatase ( $\mathrm{A}$ and $\mathrm{D}), \mathrm{DAPI}(\mathrm{B}$ and $\mathrm{E})$ and co-localization with aromatase and DAPI ( $\mathrm{C}$ and $\mathrm{F})$. The empty arrows indicate immunoreactive germ cells (spermatogonia, spermatocytes, round and elongated spermatids) stained for aromatase (A and D), DAPI (B and $\mathrm{E})$, and co-localization with aromatase and DAPI (C and F). DAPI, 4',6-diamidino-2-phenylindole. Bar $=50 \mu \mathrm{m}$.

(Nitta et al. 1993), rat (Janulis et al. 1998) and other rodents (Schmalz-Fraczek et al. 1999) but none to our knowledge in hystricomorph rodents. Expression of P450arom in the post-pubertal sexual phase was similar to the pubertal phase, but P450arom was apparently also expressed in spermatocytes (pachytene). In adult mice, expression of P450arom was similar to G. spixii, with expression not only in Leydig cells, but also in spermatocytes, spermatids and spermatozoa (Janulis et al. 1998). As in dogs, P450arom had an abrupt increase during aging in mRNA levels (Ogawa et al. 2016). It was hypothesized that the increased expression of P450arom and additional estradiol production promotes spermatogonial stem cell proliferation, acrosome formation and spermatids maturation (Schulster et al. 2016, Janulis et al. 1996, Shetty et al. 1997).

Leydig cells appeared to be the major source of androgens in G spixii. The enzyme P450c17 is responsible for conversion of pregnanes to androstanes, either $\Delta 4$ and/or $\Delta 5$ pregnanes depending on species (Conley \& Bird 1997). Based on IHC and qPCR transcript analyses, other tissues in mammals, including brain, adrenal glands, gonads, skin, liver and kidney (Hammar \& Peterson 1986, Nolan \& Payne 1990,

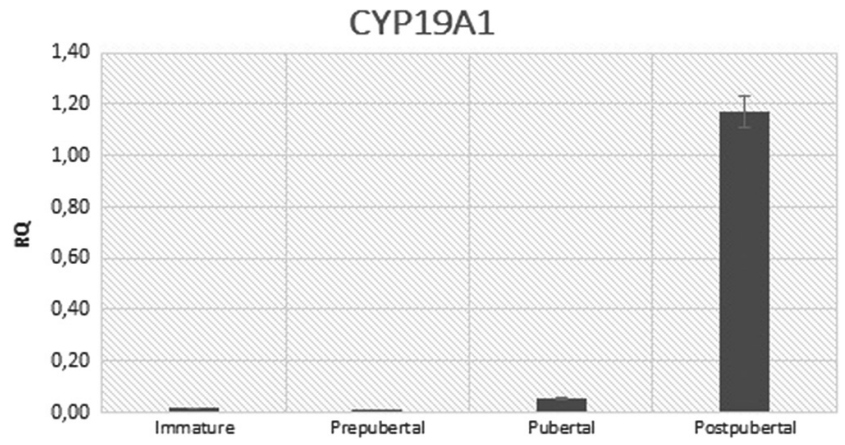

Figure 6 Relative gene expression normalized with GAPDH and $A C T B$ as reference genes of P450aromatase (CYP19A1) in testis collected from immature, pre-pubertal, pubertal and post-pubertal G. spixii. Data are the means.
O'Shaughnessy et al. 2000, Weng et al. 2005, Tagawa et al. 2006, Almeida et al. 2011) may also express P450c17 depending on species. Synthesis in these tissues may influence local tissue concentrations of sex steroids, even if systemic concentrations originate primarily from testicular production. Immunostaining for P450c17 was positive in interstitial cells of G. spixii, in Leydig cell clusters, from immature to post-pubertal animals. In rats, starting from 15.5 days of gestation, the P450c17 enzyme was present only in fetal Leydig cells and their expression increase in gestational day 18.5 and remained high until the first week after birth. In this

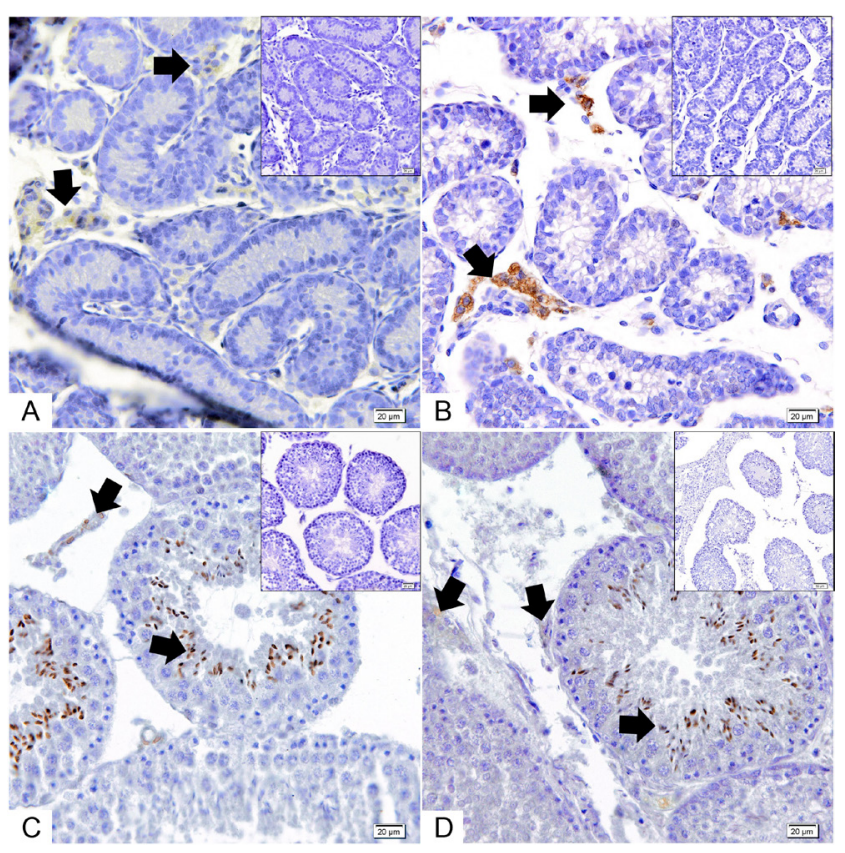

Figure 7 NADPH cytochrome P450 oxidoreductase (CPR) expression in the testicular parenchyma of G. spixii during sexual development. In immature (A) and pre-pubertal (B) testes, positive staining was observed only in the Leydig cells (bold arrow). In pubertal (C) and post-pubertal (D) testes, expression was positive in Leydig cells and germ cells (round and elongated spermatids). Inserts represent the negative controls. Bar $=20 \mu \mathrm{m}$. 
period, production of testicular testosterone starts, which is important for development of male genital organs and testes (Majdič et al. 1998). Expression of P450c17 during postnatal testis development in horses was also positive only in Leydig cells, with an increase in enzyme expression from pre-pubertal to adulthood (Almeida et al. 2011). The catalytic activity of P450c17 and P450 aromatase is also totally dependent on expression and interaction with CPR. Like P450c17 and P450arom expression, immunoreactivity for CPR-labeled clusters of Leydig cells and germ cells of $G$ spixii is consistent with the potential for supporting microsomal P450 activity in these cells.

In conclusion, Leydig cells were the major cellular source of androgens and estrogens during sexual development of the hystricomorph rodent, G spixii, Expression of P450arom when detected was considerably less in Sertoli cells, and in germ cells, which may supplement estrogen synthesis to some degree, supporting testicular function and spermatogenesis. If representative of others in this taxon, these data suggest that the cellular partitioning of sex steroid synthesis in the testes of hystricomorpha shares many similarities with rats, mice and other rodents.

\section{Declaration of interest}

The authors declare that they have no conflict of interest in relation to the development and publication of the study.

\section{Funding}

This work was supported by the São Paulo State Research Foundation (FAPESP, grant number 2012/11217-8) and Conselho Nacional de Desenvolvimento Científico e Tecnológico (grant number 402220/2010-2).

\section{Acknowledgements}

The authors thank members of the University of Sao Paulo (FMVZ), Brazil, for technical support. They warmly thank Dr John Kastelic and Rose Kastelic for help with the English.

\section{References}

Almadhidi J, Seralini GE, Fresnel J, Silberzahn P \& Gaillard JL 1995 Immunohistochemical localization of cytochrome P450 aromatase in equine gonads. Journal of Histochemistry and Cytochemistry 43 571-577. (doi:10.1177/43.6.7769228)

Almeida J, Conley AJ, Mathewson L \& Ball BA 2011 Expression of steroidogenic enzymes during equine testicular development. Reproduction 141 841-848. (doi:10.1530/REP-10-0499)

Berger T, Conley AJ, Van Klompenberg M, Roser JF \& Hovey RC 2013 Increased testicular Sertoli cell population induced by an estrogen receptor antagonist. Molecular and Cellular Endocrinology 366 53-58. (doi:10.1016/j.mce.2012.11.011)

Bilinska B, Lesniak M \& Schmalz B 1997 Are ovine Leydig cells able to aromatize androgens? Reproduction, Fertility and Development $\mathbf{9}$ 193-199. (doi:10.1071/R96038)
Bilińska B, Drag E \& Schmalz-Fraczek B 1999 Immunolocalization of androgen receptors in testicular cells during postnatal development of the bank vole (Clethrionomys glareolus, S.). Tissue Cell 31 621-626. (doi:10.1054/tice.1999.0078)

Bilinska B, Schmalz-Fraczek B, Kotula M \& Carreau S 2001 Photoperioddependent capability of androgen aromatization and the role of estrogens in bank vole testis visualized by means of immunohistichemistry. Molecular and Cellular Endocrinology 178 189-198. (doi:10.1016/ S0303-7207(01)00427-0)

Carreau S, Genissel C, Bilinska B \& Levallet J 1999 Sources of oestrogen in the testis and reproductive tract of the male. Journal of Andrology 22 211-223. (doi:10.1046/j.1365-2605.1999.00172.x)

Carreau S, Bourguiba S, Lambard S, Silandre D \& Delalande C 2004 The promoter(s) of the aromatase gene in male testicular cells. Reproductive Biology 4 23-34.

Carreau S, Silandre D, Bois C, Bouraima H, Galeraud-Denis I \& Delalande C 2007 Estrogens: a new player in spermatogenesis. Folia Histochemica and Cytobiologica 45 5-10. (doi:10.1016/S1642431X(12)60065-5)

Conley AJ \& Bird IM 1997 The role of cytochrome P450 17 alphahydroxylase and 3 beta-hydroxysteroid dehydrogenase in the integration of gonadal and adrenal steroidogenesis via the delta 5 and delta 4 pathways of steroidogenesis in mammals. Biology of Reproduction $\mathbf{5 6}$ 789-799. (doi:10.1095/biolreprod56.4.789)

Conley AJ \& Hinshelwood M 2001 Mammalian aromatases. Reproduction 121 685-695. (doi:10.1530/rep.0.1210685)

Conley AJ, Corbin CJ, Hinshelwood M, Liu Z, Simpson ER, Ford JJ \& Harada N 1996 Functional aromatase expression in porcine adrenal gland and testis. Biology of Reproduction 54 497-505. (doi:10.1095/ biolreprod54.2.497)

Eisenhauer KM, Mccue PM, Nayden DK, Osawa Y \& Roser JF 1994 Localization of aromatase in equine Leydig cells. Domestic Animal Endocrinology 11 291-298. (doi:10.1016/0739-7240(94)90020-5)

Hammar M \& Petersson F 1986 Testosterone production in vitro in human testiculartissue. Andrologia 18196-200. (doi:10.1111/j.1439-0272.1986. tb01761.x)

Janulis L, Hess R, Bunick D, Nitta H, Janssen S, Asawa Y \& Bahr JM 1996 Mouse which epididymal decreases sperm as sperm contain traverse active P450 aromatase the epididymis. Journal of Andrology 17 111-116. (doi:10.1002/j.1939-4640.1996.tb01759.x)

Janulis L, Bahr JM, Hess RA, Janssen S, Osawa Y \& Bunick D 1998 Rat testicular germ cells and epididymal sperm contain active $\mathrm{P} 450$ aromatase. Journal of Andrology 19 65-71. (doi:10.1002/j.1939-4640.1998. tb02471.x)

Kopera I, Szczepanowicz M, Gizejewski Z, Sadowska J \& Bilinska B 2010 Immunoexpression of aromatase in immature and adult males of the European bison (Bison bonasus, Linnaeus 1758). Reproduction in Domestic Animals 45 269-274. (doi:10.1111/j.14390531.2008.01280.x)

Kotula-Balak M, Slomczynska M, Fraczek B, Bourguiba S, Tabarowski Z, Carreau S \& Bilinska B 2003 Complementary approaches demonstrate that cellular aromatization in the bank vole testis is related to photoperiod. European Journal of Histochemistry 47 55-62. (doi:10.4081/807)

Kurosumi M, Ishimura K, Fujita H \& Osawa Y 1985 Immunocytochemical localization of aromatase in rat testis. Histochemistry 83 401-404. (doi:10.1007/BF00509199)

Li H, Papadopoulos V, Vidic B, Dym M \& Culty M 1997 Regulation of rat testis gonocyte proliferation by platelet-derived growth factor and estradiol: identification of signaling mechanisms involved. Endocrinology 138 1289-1298. (doi:10.1210/endo.138.3.5021)

Majdic G, Saunders PTK \& Teerds KJ 1998 Immunoexpression of the steroidogenic enzymes 3-beta hydroxysteroid dehydrogenase and 17 alpha-hydroxylase, C17,20 lyase and the receptor for luteinizing hormone (LH) in the fetal rat testis suggests that the onset of Leydig cell steroid production is independent of $\mathrm{LH}$ action. Biology of Reproduction 58 520-525. (doi:10.1095/biolreprod58.2.520)

Mutembei H, Pesch S, Schuler G \& Hoffmann B 2005 Expression of oestrogen receptors alpha and beta and of aromatase in the testis of immature and mature Boars. Reproduction in Domestic Animals 40 228-236. (doi:10.1111/j.1439-0531.2005.00586.x)

Nitta H, Bunick D, Hess RA, Janulis L, Newton SC, Milette CF, Osawa Y, Shizuta Y, Toda K \& Bahr JM 1993 Germ cells of the mouse testis 
express P450 aromatase. Endocrinology 132 1396-1401. (doi:10.1210/ endo.132.3.8440194)

Nolan CJ \& Payne AH 1990 Genotype at the P450scc locus determines differences in the amount of P450scc protein and maximal testosterone production in mouse Leydig cells. Molecular Endocrinology $\mathbf{4}$ 1459-1464. (doi:10.1210/mend-4-10-1459)

O'Shaughnessy PJ, Baker PJ, Heikkilä M, Vainio S \& Mcmahon AP 2000 Localization of 17ß-hydroxysteroid dehydrogenase/17-ketosteroid reductase isoform expression in the developing mouse testisandrostenedione is the major androgen secreted by fetal/neonatal Leydig cells. Endocrinology 141 2631-2637. (doi:10.1210/endo.141.7.7545)

Ogawa E, Kawate N, Inaba T \& Tamada H 2017 Testicular gene expression of steroidogenesis-related factors in prepubertal, postpubertal, and aging dogs. Theriogenology 90 42-48. (doi:10.1016/j. theriogenology.2016.11.007).

Qiang W, Murase T \& Tsubota T 2003 Seasonal changes in spermatogenesis and testicular steroidogenesis in wild male raccoon dogs (Nyctereutes procynoides). Journal of Veterinary Medical Science 65 1087-1092. (doi:10.1292/jvms.65.1087)

Raeside JI \& Renaud RU 1983 Estrogen and androgen production by purified Leydig cells of mature boars. Biology of Reproduction $\mathbf{2 8}$ 727-733. (doi:10.1095/biolreprod28.3.727)

Robertson KM, O'Donnell L, Jones MEE, Meachem SJ, Boon WC, Fisher CR, Graves KH, McLachlan RI \& Simpson ER 1999 Impairment of spermatogenesis in mice lacking a functional aromatase (Cyp19) gene. PNAS 96 7986-7991. (doi:10.1073/pnas.96.14.7986)

Rommerts FFG 1988 How much androgen is required for maintenance of spermatogenesis?. Journal of Endocrinology 116 7-9. (doi:10.1677/ joe.0.1160007)

Santos PRS, Oliveira MF, Silva AR \& Assis Neto AC 2012 Development of spermatogenesis in captive bred spix's yellow-toothed (Galea spixii, Wagler, 1831). Reproduction, Fetility and Development 24 877-885. (doi:10.1071/RD12015)

Santos PRS, Oliveira MF, Arroyo MAM, Silva AR, Rici REG, Miglino MA \& Assis Neto AC 2014 Ultrastructure of spermatogenesis in Spix's Yellowtoothed cavy (Galea spixii). Reproduction 147 13-19. (doi:10.1530/ REP-13-0452)

Schmalz-Fraczek B, Kotula M, Carreau S \& Bilinska B 1999 Localization of androgen receptor and aromatase in bank vole testis - an imunohistochemical study. Molecular and Cellular Endocrinology 155 184 (Abstract).

Schon J \& Blottner S 2008 Estrogens are involved in seasonal regulation of spermatogenesis and sperm maturation in roe deer (Capreolus capreolus).
General and Comparative Endocrinology 159 257-263. (doi:10.1016/j. ygcen.2008.09.008)

Schulster M, Bernie AM \& Ramasamy R 2016 The role of estradiol in male reproductive function. Asian Journal of Andrology 18 435-440. (doi:10.4103/1008-682X.173932)

Shetty G, Krishnamurthy H, Krishnamurthy N, Bhatnagar AS \& Moudgal RN 1997 Effect of estrogen deprivation on the reproductive physiology of male and female primates. Journal of Steroid Biochemistry and Molecular Biology 61 157-166. (doi:10.1016/s0960-0760(97)80008-8)

Sipahutar H, Sourdaine P, Moslemi S, Plainfossé B \& Seralini GE 2003 Immunolocalization of aromatase in stallion Leydig cells and seminiferous tubules. Journal of Histochemistry and Cytochemistry $\mathbf{5 1}$ 311-318. (doi:10.1177/002215540305100306)

Tagawaa N, Katagirib M \& Kobayashi Y 2006 Developmental changes of serum steroids produced by cytochrome P450c17 in rat. Steroids 7 165-170. (doi:10.1016/j.steroids.2005.09.006)

Tsai-Morris CH, Aquilano DR \& Dufau ML 1985 Cellular localization of rat testicular aromatase activity during development. Endocrinology 116 38-46. (doi:10.1210/endo-116-1-38)

Tsubota T, Howell-Skalla L, Nitta H, Osawa Y, Mason JI, Meiers PG, Nelson RA \& Bahr JM 1997 Seasonal changes in spermatogenesis and testicular steroidogenesis in the male black bear Ursus americanus. Journal of Reproduction and Fertility 109 21-27. (doi:10.1530/jrf.0.1090021)

Weng Q, Medan MS, Ren L, Watanabe G, Tsubota T \& Taya K 2005 Immunolocalization of steroidogenic enzymes in the fetal, neonatal and adult testis of the Shiba goat. Experimental Animals 54 451-454. (doi:10.1538/expanim.54.451)

Zhang H, Sheng X, Hu X, Li X, Xu H, Zhang M, et al. 2010 Seasonal changes in spermatogenesis and immunolocalization of cytochrome P450 17alpha-hydroxylase/c17-20 lyase and cytochrome P450 aromatase in the wild male ground squirrel (Citellus dauricus Brandt). Journal of Reproduction and Development 56 297-302. http://doi.org/10.1262/ jrd.09-078T (doi:10.1262/jrd.09-078T)

Received 7 February 2017

First decision 24 March 2017

Revised manuscript received 19 July 2017

Accepted 7 August 2017 